\title{
The evolution of chemical and microbiological properties of fresh goat milk cheese during its shelf life
}

\author{
F. Masotti, ${ }^{1}$ G. Battelli, $†$ and I. De Noni ${ }^{\star}$ \\ *Dipartimento di Scienze e Tecnologie Alimentari e Microbiologiche, Università degli Studi di Milano, I-20133 Milano, Italy \\ †CNR, Istituto di Scienze delle Produzioni Alimentari, Sezione di Milano
}

\begin{abstract}
This study investigated the changes in chemical and microbiological properties of fresh goat milk cheese stored in an open deck refrigerated display cabinet (6 $\left.\pm 2^{\circ} \mathrm{C}\right)$ or in a dark cold room $\left(4 \pm 1^{\circ} \mathrm{C}\right)$. The effects of partial-vacuum packaging and fluorescent lighting were studied during the cheese shelf life $(45 \mathrm{~d})$ and $15 \mathrm{~d}$ after. Storage conditions did not affect the $\mathrm{pH}$ values (4.3), whereas a slight decrease in moisture (ca. $1 \%)$ and in water activity ( $<0.01$ units) was recorded. Proteolysis monitored by Kjeldahl determination increased significantly during storage of all samples. The highest increase from 8.5 to $13.0 \%$ of soluble nitrogen (expressed as percentage of total nitrogen) was measured in cheese packaged in the presence of air and stored in a lighted cabinet. The proteolytic trend was also studied through capillary zone electrophoresis by monitoring the degradation of the main casein fractions and the formation of new peptides. In particular, 2 indices, based on peak area ratio of new-formed peptides and casein fractions were related to cheese age. Lipolysis, measured by solid-phase microextraction gas chromatography coupled to mass spectrometry of volatile fatty acids, was unaffected by air or light and did not proceed through storage. As expected, hexanal formed mainly in cheeses stored under light and packaged in air. Evaluation of sensorial quality, performed using a hedonic scale, showed significantly lower scores of cheeses kept under light compared with those kept in the dark, both at 45 and $60 \mathrm{~d}$ storage. Overall, the microbiological and chemical results suggested that the shelf life of soft goat milk cheese would be extended from 45 to $60 \mathrm{~d}$. Such conclusion was supported also by the sensory quality evaluation.
\end{abstract}

Key words: goat cheese, proteolysis, capillary zone electrophoresis, solid-phase microextraction gas chromatography coupled to mass spectrometry

Received October 11, 2011.

Accepted April 27, 2012.

${ }^{1}$ Corresponding author: fabio.masotti@unimi.it

\section{INTRODUCTION}

Goat milk cheeses have gained popularity in the European Union due to the increased interest of consumers in both the tradition of cheesemaking and the sensorial and nutritional value attributed to goat milk. Indeed, demand for goat milk cheeses, especially for the fresh lactic varieties, has steadily increased among consumers of health and diet foods over the past 20 yr (Gabiña, 2005). These lactic-type cheeses are produced by acid coagulation through the addition of indigenous or selected lactic microflora and by addition of a small quantity of rennet. The final product has a high moisture content (50 to $65 \%$ ), a low $\mathrm{pH}$ (4.1 to 4.5$)$, and a short shelf life $(<30 \mathrm{~d})$. Italian goat milk cheese manufacturers are predominantly small cheesemaking businesses, although a few large cheese factories exist. Cheese distribution is gradually shifting from cheesemakers selling directly to their consumers from their farms to large-scale distribution through market. Consequently, an extended shelf life is required and good quality must be maintained during long-term storage. At the market, goat milk cheeses are placed in open-deck refrigerated display cabinets under different storage conditions (i.e., time, temperature, and light irradiation) compared with the cold rooms and dark conditions under which cheese is stored on farm.

The ripening of cheese includes several phenomena catalyzed by the activity of microorganisms and enzymes. Proteolysis and lipolysis are of particular interest because they are responsible for modifications of cheese texture and for formation of flavor and off-flavor (Fox et al., 2000). Proteolysis and lipolysis of goat milk have been discussed by Park (2001). That author reviewed the major factors affecting these biochemical phenomena and the methods used for their analysis. The effects of storage at $4^{\circ} \mathrm{C}$ of fresh caprine milk cheese were studied by Van Hekken et al. (2005) in terms of both proteolysis by SDS-PAGE and rheology. Park et al. (2006) studied the evolution of the organic acid profile in soft goat milk cheese after 14- and 28-d shelf life. A variety of analytical methods can be used to monitor cheese ripening, and in particular, HPLC 
and capillary electrophoresis have been extensively used to study proteolysis (Sousa et al., 2001), whereas GC-MS of VFA has been proposed to evaluate lipolysis (Fox et al., 2000).

As goat milk cheeses are usually sold in transparent packages and stored under fluorescent light (the primary display light source) at markets, photo-oxidation of lipids should also be considered. In this regard, GC-MS of hexanal has been proposed as a useful index to monitor this phenomenon (Singh and Cadwallader, 2004).

To date, information on the effects of market storage conditions on the chemical and microbiological phenomena taking place during the shelf life of fresh goat milk cheese is lacking. In this work, fresh goat milk cheese was the subject of the research. The objectives of the study were (1) to determine the effect of storage conditions both at market and at the cheese factory mainly on chemical and microbiological properties, (2) to evaluate the prolongation of shelf life from 45 to 60 d, and (3) to study the proteolytic pattern measured by capillary zone electrophoresis (CZE), for cheese characterization.

\section{MATERIALS AND METHODS}

\section{Cheesemaking}

Goat milk from Alpine and Saanen breeds was supplied by local farmers from northern Italy. A lactic-type goat milk cheese was manufactured using a horizontal stainless steel vat of $650-\mathrm{L}$ capacity. Milk was thermized in batch at $64^{\circ} \mathrm{C}$ for $10 \mathrm{~min}$, cooled at $25^{\circ} \mathrm{C}$, and inoculated with a mesophilic starter culture of lactic acid bacteria (LAB). After a 3 -h fermentation, liquid calf rennet $(4-5 \mathrm{~mL} / 650 \mathrm{~L}$; strength units 1:10,000; chymosin to pepsin ratio 75:25) was added to the milk, and the curd was allowed to stand for $24 \mathrm{~h}$. After whey draining, the curd was mechanically kneaded with the addition of salt ( $15 \mathrm{~g} / \mathrm{kg}$ of cheese) and potassium sorbate $(1 \mathrm{~g} / \mathrm{kg}$ of cheese), and ripened in basins for $7 \mathrm{~d}$ at 1 to $2^{\circ} \mathrm{C}$. Finally, the curd was molded into cylindrical shapes (150 g; diameter $6 \mathrm{~cm}$ ). The cheese yield was ca. $15 \%$. Two batches of cheese were manufactured on 2 successive days.

\section{Experimental Design}

The molded cheeses were packaged in air in rigid plastic bags (polystyrene) with transparent covers. The cheese-to air-ratio was ca. 55:45 ( vol/vol). Half of the packaged cheese sample was put into a pouch (polyamide $20 \mu \mathrm{m} /$ polyethylene $60 \mu \mathrm{m}$ with ethylene vinyl acetate) under partial vacuum (ca. $70 \mathrm{kPa}$; vacuum bag sealer Multiple 1000/B; Lavezzini Srl, Piacenza, Italy).
Sealed bag cheeses were stored either in an open-deck refrigerated display cabinet $\left(6 \pm 2^{\circ} \mathrm{C}\right)$ under fluorescent light provided by a cool white fluorescent tube $(58 \mathrm{~W}$, 4,100-4,200 K; Osram, Milan, Italy) or in a cold room in the dark $\left(4 \pm 1^{\circ} \mathrm{C}\right)$. Samples packaged in air were kept in a cold room (AR) or in a refrigerated cabinet (AC). Samples packaged under partial vacuum were stored in a cold room (VR) or a refrigerated cabinet (VC) and sampled at 7, 15, 30, 45, and $60 \mathrm{~d}$ from cheesemaking. For all of these cheeses, the shelf life provided by the cheesemaker was $45 \mathrm{~d}$. At each sampling time, 2 packaged cheese samples of each batch were mixed thoroughly by intensive kneading. Mixed samples from each batch were analyzed at least in duplicate.

\section{Chemical Analyses}

Milk. Unprocessed and thermized goat milk samples were analyzed for $\mathrm{pH}$ and alkaline phosphatase activity according to the standard of the International Organization for Standardization/International Dairy Federation (ISO/IDF, 2006).

Cheese. Moisture was gravimetrically measured by drying in a laboratory oven at $102 \pm 2^{\circ} \mathrm{C}$ according to the ISO/IDF (2004) standard. Potentiometric determination (micropH 2001; Crison Strumenti SpA, Modena, Italy) of $\mathrm{pH}$ was performed on the water-soluble extract obtained by cheese centrifugation. A dew point hygrometer (AquaLab; Decagon Devices Inc., Pullman, WA) was used to measure water activity.

\section{Microbiological Analyses}

The cheese (20 g) was transferred aseptically into a bag, dispersed in $90 \mathrm{~mL}$ of citrate buffer $(2 \%$, wt/vol) and the mixture was homogenized using a Stomacher 400 (Seward Laboratory, London, UK) for $60 \mathrm{~s}$. Serial dilutions of the sample homogenate were prepared in $0.1 \%$ sterile peptone water and inoculated in growth media for the estimation of microbial counts. During cheese storage, the enumeration of Pseudomonas spp. (Pseudomonas agar base) was performed at $37 \pm 1^{\circ} \mathrm{C}$ for $48 \mathrm{~h}$ (ICMSF, 1978), total coliforms (3M Petrifilm; $3 \mathrm{M}$ Co., St. Paul, MN) at $32 \pm 1^{\circ} \mathrm{C}$ for $24 \mathrm{~h}$ (AOAC, 2000a), LAB [de Man, Rogosa, and Sharpe (MRS) agar] at $37^{\circ} \mathrm{C}$ for $48 \mathrm{~h}$ (IDF, 1997), and yeasts and molds (3M Petrifilm) at room temperature for $5 \mathrm{~d}$ (AOAC, 2000b).

\section{Evaluation of Proteolysis by the Kjeldahl Method and CZE}

Proteolysis was assessed by Kjeldahl determination of the $\mathrm{pH}$ 4.4-soluble nitrogen content from a citrate 
dispersion of cheese (ISO/IDF, 2010) and the values were expressed as percentage of the total nitrogen, measured by the Kjeldahl method (ISO/IDF, 2001). Casein fractions and derived peptides were studied using the CZE method provided by Recio et al. (1997). One gram of cheese or $2.5 \mathrm{~mL}$ of milk was added to $10 \mathrm{~mL}$ of the $10 M$ urea buffer (Masotti et al., 2010) and let stand for at least $4 \mathrm{~h}$ for protein solubilization. Next, the solution was diluted with the same buffer (1:4), filtered on a $0.22-\mu \mathrm{m}$ disposable filter and analyzed. Analyses were carried out on a Beckman $\mathrm{P} / \mathrm{ACE}$ system MDQ (Beckman Instruments Inc., Fullerton, CA). A coated capillary column (DB-WAX; J \& W Agilent Technologies Inc., Santa Clara, CA) was used, and UV detection was realized at $214 \mathrm{~nm}$. Normalized peak areas were calculated as peak area/migration time. Casein fractions were identified by comparison with data reported in the literature (Recio et al., 1997). Peptides were identified by comparing migration time with those of peptides present in the patterns of in vitro enzymatic hydrolysates of the thermized goat milk.

\section{Analyses of VFA and Hexanal by Solid-Phase Microextraction Gas Chromatography Coupled to Mass Spectrometry}

Analysis of VFA (C4-C10) and hexanal was performed on the head-space of fat extracted by centrifugation from the cheese added to anhydrous sodium sulfate (3:1; De Noni and Battelli, 2008). Two milliliters of cheese fat was poured in a head-space crimp-top glass bottle (Agilent Technologies Inc.) sealed with a polytetrafluoroethylene (PTFE)-silicone septum and introduced in the solid-phase microextraction (SPME) autosampler. For the head-space SPME sampling, a Combi-Pal automated sampler (CTC Analytics AG, Zwingen, Switzerland) coupled to an Agilent 6890 gas chromatograph with an Agilent 5975 mass spectrometric detector was used (Battelli et al., 2011). To obtain equilibrium, a vial containing sample was stirred at $250 \mathrm{rpm}$ for $10 \mathrm{~min}$ at $50^{\circ} \mathrm{C}$. The SPME was performed using a DVB/CAR/PDMS 50/30 $\mu \mathrm{m}$ fiber (Supelco Inc., Bellefonte, PA), which was exposed to the headspace of cheese fat for $40 \mathrm{~min}$ at $50^{\circ} \mathrm{C}$ during stirring and desorbed in the injection port of the GC at $260^{\circ} \mathrm{C}$ for $10 \mathrm{~min}$. Analytes were separated using a J \& W DB-WAXetr column $(60 \mathrm{~m} \times 0.25 \mathrm{~mm}$, film thickness $0.25 \mu \mathrm{m}$; Agilent Technologies Inc.). Helium was used as the carrier gas working in a constant pressure mode $(150 \mathrm{kPa}$, corresponding to $1.4 \mathrm{~mL} / \mathrm{min}$ at $45^{\circ} \mathrm{C}$ ). The injection port was $260^{\circ} \mathrm{C}$, the split ratio was $3.57: 1$, and total flow was $8.5 \mathrm{~mL} / \mathrm{min}$. The oven was programmed at $45^{\circ} \mathrm{C}$ (5-min hold) and ramped up to $219^{\circ} \mathrm{C}$ at $6^{\circ} \mathrm{C} / \mathrm{min}$ (16-min hold). The transfer line to the mass spectrometer was maintained at $280^{\circ} \mathrm{C}$, the ion source was $230^{\circ} \mathrm{C}$, and the quadrupole was $150^{\circ} \mathrm{C}$. Acquisition was performed in electronic impact mode. The mass range used was 39 to $200 \mathrm{amu}$. The volatile compounds were identified using the Wiley 7n-1 MS library on Agilent MSD ChemStation software (Agilent Technologies Inc.). Confirmation of the identity of the volatile compounds was achieved by comparing the GC retention indices and mass spectra of individual components with those of authentic reference compounds injected under the same operating conditions. The data collected refer to the peak area of the quant ion of each compound.

\section{In Vitro Enzymatic Hydrolysis of Thermized Goat Milk}

Liquid calf rennet (160 international milk clotting units/mL, chymosin to pepsin 79:21; Chr. Hansen Italia SpA, Parma, Italy) and plasmin (fibrinolysin from bovine plasma, E.C. 3.4.21.7; Roche Diagnostics GmbH, Mannheim, Germany) were used. International milk clotting units of $0.25 \mathrm{U} / \mathrm{mL}$ of calf rennet and $6.0 \times$ $10^{-2} \mathrm{U} / \mathrm{mL}$ of plasmin were added both to the thermized goat milk and to the same milk acidified to $\mathrm{pH}$ $4.0(0.1 \mathrm{~N} \mathrm{HCl})$. Enzymatic hydrolyses were performed at $37^{\circ} \mathrm{C} / 3 \mathrm{~h}$. The hydrolysates were mixed (1:1) with the $10 M$ urea buffer (Masotti et al., 2010) to stop the reaction, filtered on a $0.22-\mu \mathrm{m}$ disposable filter and submitted to CZE analysis. All analyses were carried out in duplicate, unless otherwise specified.

\section{Sensory Quality Evaluation}

Sensory quality of cheeses after 45 and $60 \mathrm{~d}$ of storage was assessed by 21 untrained panelists. For each panel session, approximately 10-g samples of cheese were placed in small plastic trays. The samples were allowed to stand for $2 \mathrm{~h}$ before the examination to allow equilibration at room temperature. Quality was scored using an unanchored line scale anchored on the left with dislike/low quality and on the right with like/extremely high quality. The hedonic scale results were converted as distance $(\mathrm{cm})$ of mark from the left end of the line.

\section{Statistical Analyses}

Data were submitted to ANOVA by Statistica 7.1 for Windows (StatSoft Inc., Tulsa, OK). Data were analyzed using the Tukey multiple comparisons method. A $P$-value $<0.05$ was considered significant. 


\section{RESULTS AND DISCUSSION}

\section{Chemical Properties}

Unprocessed goat milk showed a $\mathrm{pH}$ value of 6.53 and its alkaline phosphatase activity was $58,270 \mathrm{mU} / \mathrm{L}$, in accordance with data reported for this type of milk (Barbosa, 2005). For safety purposes, milk was submitted to in-batch heating at $64^{\circ} \mathrm{C}$ for $10 \mathrm{~min}$ before cheesemaking. An incomplete inactivation of alkaline phosphatase $(923 \mathrm{mU} / \mathrm{L})$ was recorded. The effectiveness of the thermization process was in accordance with data reported in the literature (Klotz et al., 2008).

The mean values of the chemical parameters of the cheeses that were observed throughout the storage period $(60 \mathrm{~d})$ are given in Table 1 . The long fermentation step and the following ripening in basins allowed the curd $\mathrm{pH}$ value to decrease to 4.34 . This value did not vary $(P<0.05)$ during cheese storage $(4.28$ to 4.33$)$ irrespective of the different storage conditions. During 24-wk storage at $4^{\circ} \mathrm{C}$ of a plain soft goat milk cheese, Park (2001) observed no variation of $\mathrm{pH}$ values until 56 d of storage. Park et al. (2006) and Van Hekken et al. (2005) also reported a steady flat trend during $28 \mathrm{~d}$ of cold storage of goat milk cheese.

The moisture content of the analyzed cheeses varied, and a random trend was observed. Only a slight decrease ( 0.4 to $2.0 \%$ for $\mathrm{VC}$ and $\mathrm{AC}$ samples, respectively) was measured after $60 \mathrm{~d}$ of storage. As described in Table 1, the water activity values were similar (0.987 to 0.992 ) until the declared shelf life (i.e., $45 \mathrm{~d}$ ), and the parameter subsequently decreased $(P<0.05)$. Overall, data show that the chemical parameters of this lactic-type goat milk cheese were scarcely affected by the different time, temperature, and lighting conditions adopted during shelf life.

\section{Microbiological Properties}

Lactic acid bacteria were the representative microorganisms of this cheese (7.12 log cfu/g). As expected, because of the microaerophilic nature of LAB, the adopted packaging conditions did not affect their growth (results not shown). Indeed, less than a 1.5 log decrease was observed for LAB count during the 60 -d storage apart from the AC sample at $45 \mathrm{~d}$. The Pseudomonas spp. count was $4.52 \log \mathrm{cfu} / \mathrm{g}$ in the fresh cheese, likely as a result of contamination after heat treatment or during cheesemaking. This count slowed down steadily during storage, regardless of packaging type or light exposure. Indeed, these spoilage microorganisms were not detectable $(<2.0 \mathrm{log} \mathrm{cfu} / \mathrm{g})$ in any of the cheese samples after $60 \mathrm{~d}$. This decrease could be attributed to the strong acidic medium and to the competition with LAB. The addition of potassium sorbate kept the mold count very low during the ripening period (always $<2.0$ $\log \mathrm{cfu} / \mathrm{g})$. Yeasts were found in the natural microflora of this cheese (4.12 log cfu/g) and, in general, cheese samples stored in the dark cold room showed the lowest contamination.

\section{Proteolysis}

The mean levels of primary proteolysis, measured by pH 4.4-soluble nitrogen content, increased progressively

Table 1. Values of $\mathrm{pH}$, moisture, and water activity $\left(\mathrm{a}_{\mathrm{w}}\right.$; mean of 6 replications $\pm \mathrm{SD}$ ) of fresh goat cheese during shelf life under different storage conditions

\begin{tabular}{|c|c|c|c|c|c|c|}
\hline Variable & $\begin{array}{l}\text { Storage } \\
\text { conditions }\end{array}$ & \multicolumn{5}{|c|}{ Storage time $(\mathrm{d})$} \\
\hline \multirow[t]{3}{*}{$\mathrm{pH}$} & $\mathrm{AC}$ & $4.28 \pm 0.02^{\mathrm{ab}}$ & $4.31 \pm 0.03^{\mathrm{a}, \mathrm{A}}$ & $4.27 \pm 0.03^{\mathrm{b}, \mathrm{A}}$ & $4.32 \pm 0.01^{\mathrm{a}, \mathrm{A}}$ & $4.32 \pm 0.02^{\mathrm{a}, \mathrm{A}}$ \\
\hline & $\mathrm{AR}$ & $4.28 \pm 0.02^{\mathrm{a}}$ & $4.31 \pm 0.02^{\mathrm{a}, \mathrm{A}}$ & $4.29 \pm 0.04^{\mathrm{a}, \mathrm{A}}$ & $4.30 \pm 0.02^{\mathrm{a}, \mathrm{A}}$ & $4.32 \pm 0.02^{\mathrm{a}, \mathrm{A}}$ \\
\hline & VR & $4.28 \pm 0.02^{\mathrm{a}}$ & $4.32 \pm 0.02^{\mathrm{a}, \mathrm{A}}$ & $4.28 \pm 0.02^{\mathrm{a}, \mathrm{A}}$ & $4.31 \pm 0.02^{\mathrm{a}, \mathrm{A}}$ & $4.33 \pm 0.02^{\mathrm{a}, \mathrm{A}}$ \\
\hline Moisture (\%) & $\mathrm{AC}$ & $64.50 \pm 0.11^{\mathrm{a}}$ & $63.42 \pm 0.08^{\mathrm{bd}, \mathrm{A}}$ & $64.07 \pm 0.12^{\mathrm{c}, \mathrm{A}}$ & $63.77 \pm 0.17^{\mathrm{bc}, \mathrm{A}}$ & $63.24 \pm 0.14^{\mathrm{d}, \mathrm{A}}$ \\
\hline \multirow[t]{4}{*}{$\mathrm{a}_{\mathrm{w}}$} & $\mathrm{AC}$ & $0.988 \pm 0.002^{\mathrm{a}}$ & $0.990 \pm 0.001^{\mathrm{a}, \mathrm{A}}$ & $0.990 \pm 0.001^{\mathrm{a}, \mathrm{AB}}$ & $0.987 \pm 0.002^{\mathrm{a}, \mathrm{A}}$ & $0.981 \pm 0.001^{\mathrm{b}, \mathrm{A}}$ \\
\hline & $\mathrm{VC}$ & $0.988 \pm 0.002^{\mathrm{a}}$ & $0.987 \pm 0.001^{\mathrm{a}, \mathrm{B}}$ & $0.991 \pm 0.001^{\mathrm{b}, \mathrm{A}}$ & $0.989 \pm 0.001^{\mathrm{ab}, \mathrm{A}}$ & $0.982 \pm 0.001^{\mathrm{c}, \mathrm{A}}$ \\
\hline & $\mathrm{AR}$ & $0.988 \pm 0.002^{\mathrm{a}}$ & $0.991 \pm 0.001^{\mathrm{b}, \mathrm{A}}$ & $0.990 \pm 0.001^{\mathrm{b}, \mathrm{AB}}$ & $0.987 \pm 0.001^{\mathrm{a}, \mathrm{A}}$ & $0.984 \pm 0.001^{\mathrm{c}, \mathrm{AB}}$ \\
\hline & VR & $0.988 \pm 0.002^{\mathrm{ac}}$ & $0.992 \pm 0.001^{\mathrm{b}, \mathrm{A}}$ & $0.988 \pm 0.001^{\mathrm{a}, \mathrm{B}}$ & $0.988 \pm 0.002^{\mathrm{ac}, \mathrm{A}}$ & $0.986 \pm 0.002^{\mathrm{c}, \mathrm{B}}$ \\
\hline
\end{tabular}

\footnotetext{
${ }^{\mathrm{a}-\mathrm{d}}$ Means within a row with different lowercase superscript letters significantly differ $(P<0.05)$.

${ }^{\mathrm{A}-\mathrm{D}}$ Means within a column with different uppercase superscript letters significantly differ $(P<0.05)$.

${ }^{1} \mathrm{AC}=$ air packaging and storage in a display cabinet $\left(6^{\circ} \mathrm{C}\right)$ under fluorescent light; $\mathrm{VC}=$ partial-vacuum packaging and storage in a display cabinet $\left(6^{\circ} \mathrm{C}\right)$ under fluorescent light; $\mathrm{AR}=$ air packaging and storage in a dark room $\left(4^{\circ} \mathrm{C}\right) ; \mathrm{VR}=$ partial-vacuum packaging and storage in a dark room $\left(4^{\circ} \mathrm{C}\right)$.
} 


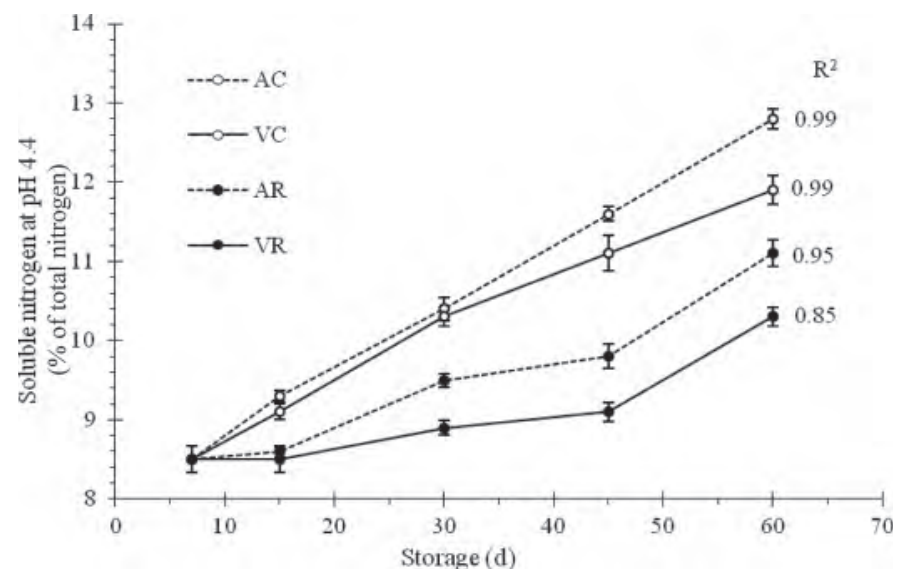

Figure 1. Effect of storage conditions on the evolution of $\mathrm{pH}$ 4.4-soluble nitrogen content during the shelf life of fresh goat milk cheese. Error bars indicate standard deviations of duplicate analyses. $\mathrm{AC}=$ air packaging and storage in a display cabinet $\left(6^{\circ} \mathrm{C}\right)$ under fluorescent light; $\mathrm{VC}=$ partial-vacuum packaging and storage in a display cabinet $\left(6^{\circ} \mathrm{C}\right)$ under fluorescent light; $\mathrm{AR}=$ air packaging and storage in a dark room $\left(4^{\circ} \mathrm{C}\right) ; \mathrm{VR}=$ partial-vacuum packaging and storage in a dark room $\left(4^{\circ} \mathrm{C}\right)$.

during storage, regardless of packaging conditions (Figure 1). The increase of proteolysis was particularly evident for samples stored in the cabinet. In this case, the coefficients of determination of the linear fitting lines were 0.99 and 0.99 for $\mathrm{AC}$ and $\mathrm{VC}$ cheeses, respectively. At the end of storage $(60 \mathrm{~d})$, the highest $(12.8 \%$ of total nitrogen) and the lowest (10.3\% of total nitrogen) values were observed in the AC and VR samples, respec- tively. In comparison to the initial values, the increase of acid-soluble nitrogen content was 51 and $21 \%$ for $\mathrm{AC}$ and VR samples, respectively. The different extent of proteolysis was likely due to the different storage temperature of samples kept in the display cabinet $(6$ $\left.\pm 2^{\circ} \mathrm{C}\right)$ or in the cold room $\left(4 \pm 1^{\circ} \mathrm{C}\right)$. In general, such results were in agreement with those of Park (2001), who reported an increasing trend of water-soluble nitrogen in a plain soft goat milk cheese stored at $4^{\circ} \mathrm{C}$ from 14 to $56 \mathrm{~d}$.

Proteolysis was also investigated by analyzing the protein/peptide profile of the cheese samples by CZE. On this basis and by comparison with the patterns reported in the literature (Recio et al., 1997), the goat milk used in this study was phenotypically characterized by the presence of the AA variant of $\alpha_{\mathrm{s} 1}$-CN and by a medium content of this fraction, as shown in Figure 2 . The differently phosphorylated forms of $\beta-\mathrm{CN}$ $\left(\beta_{2}\right.$ and $\left.\beta_{1}\right)$ were identified by comparison with CZE patterns of Molina et al. (2000). Gamma 2 casein was identified following the in vitro digestion of thermized goat milk with bovine plasmin, whereas $\gamma_{1^{-}}$and $\gamma_{3}$-CN migrated with the $\alpha_{s 1}-C N$ (results not shown). In the same way, the disappearance of $\kappa-\mathrm{CN}$ and the concurrent formation of para- $\kappa-\mathrm{CN}$ were observed in the curd pattern following the action of rennet. During storage, a decrease in $\alpha_{\mathrm{s}^{-}}$and $\beta-\mathrm{CN}$ content was observed in agreement with results of Park (2001).

The almost complete disappearance of $\alpha_{\mathrm{s} 1}-\mathrm{CN}$ fractions and the simultaneous increase of other minor

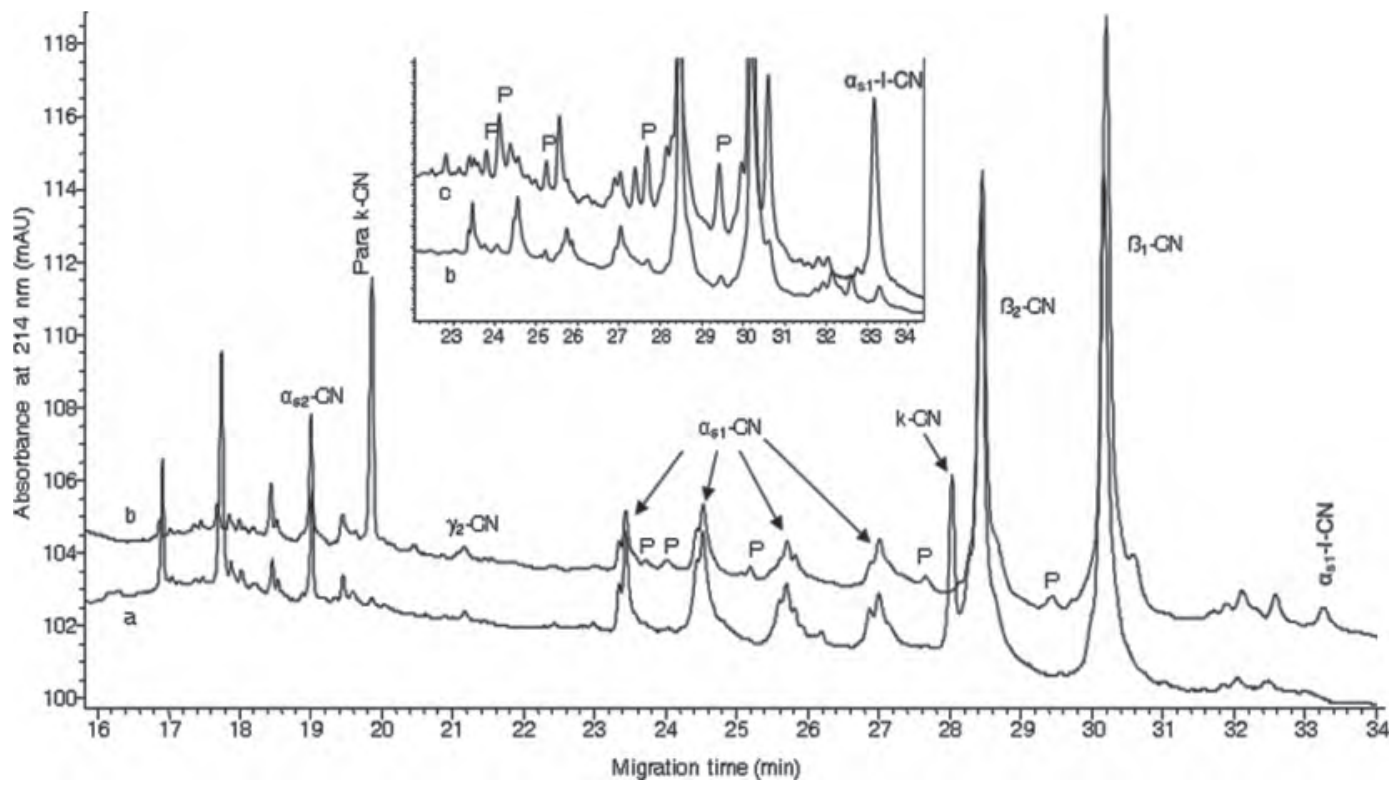

Figure 2. Capillary zone electrophoresis of (a) raw goat milk and (b) fresh goat milk cheese after 30-d storage under partial-vacuum packaging in a dark room $\left(4^{\circ} \mathrm{C}\right)$. Inner box: (c) pattern of thermized goat milk acidified to $\mathrm{pH} 4.0$ and hydrolyzed by rennet at $37^{\circ} \mathrm{C}$ for $3 \mathrm{~h}$. $\mathrm{P}=$ peptides formed after rennet hydrolysis $\left(37^{\circ} \mathrm{C}\right.$ for $\left.3 \mathrm{~h}\right)$ of thermized goat milk acidified to $\mathrm{pH} 4.0$. 

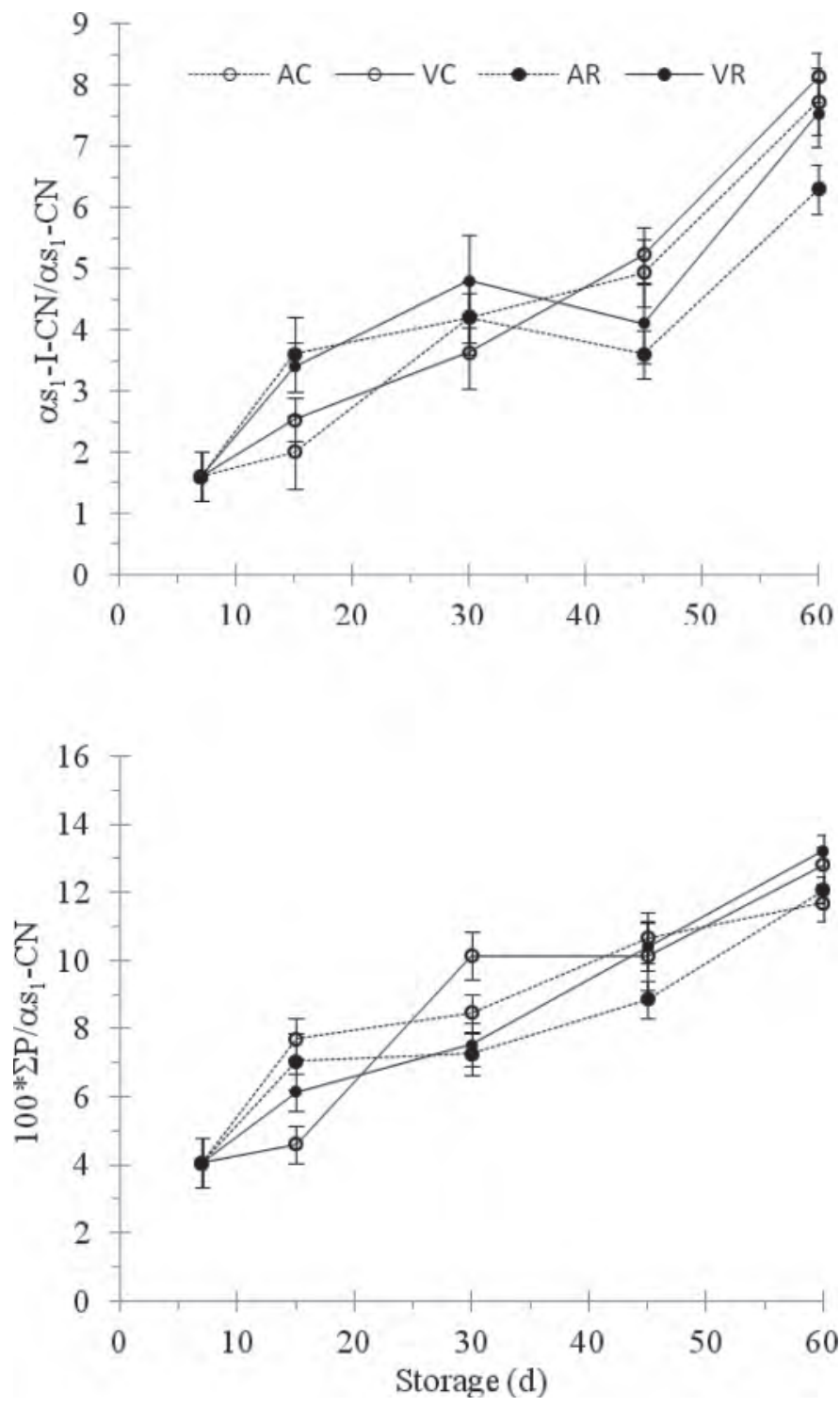

Figure 3. Evolution of the capillary zone electrophoresis (CZE) peak areas of $\alpha_{\mathrm{s} 1}$-I-CN and peptides formed after rennet hydrolysis $\left(37^{\circ} \mathrm{C}\right.$ for $\left.3 \mathrm{~h}\right)$ of thermized goat milk acidified to $\mathrm{pH} 4.0(\mathrm{P})$ during storage of soft goat milk cheese. Error bars indicate standard deviations of duplicate analyses. $\mathrm{AC}=$ air packaging and storage in a display cabinet $\left(6^{\circ} \mathrm{C}\right)$ under fluorescent light; $\mathrm{VC}=$ partial-vacuum packaging and storage in a display cabinet $\left(6^{\circ} \mathrm{C}\right)$ under fluorescent light; $\mathrm{AR}=$ air packaging and storage in a dark room $\left(4^{\circ} \mathrm{C}\right) ; \mathrm{VR}=$ partial-vacuum packaging and storage in a dark room $\left(4^{\circ} \mathrm{C}\right)$.

electrophoretic peaks ( $\mathrm{P}$ in Figure 2) were observed throughout cheese storage. When the thermized goat milk was in vitro hydrolyzed with rennet $\left(\right.$ at $37^{\circ} \mathrm{C}$ for $3 \mathrm{~h}$ ), any decrease in $\alpha_{\mathrm{s} 1}-\mathrm{CN}$ content was recorded. In contrast, the minor peaks $\mathrm{P}$ and the $\alpha_{\mathrm{s} 1}-\mathrm{I}-\mathrm{CN}$ peptide formed in the acidified milk ( $\mathrm{pH} 4.0)$ when hydrolyzed by the same enzyme (Figure 2, box). We supposed the minor peaks $\mathrm{P}$ of Figure 2 originated from $\alpha_{\mathrm{s} 1}-\mathrm{CN}$ proteolysis by action of rennet. Indeed, a progressive

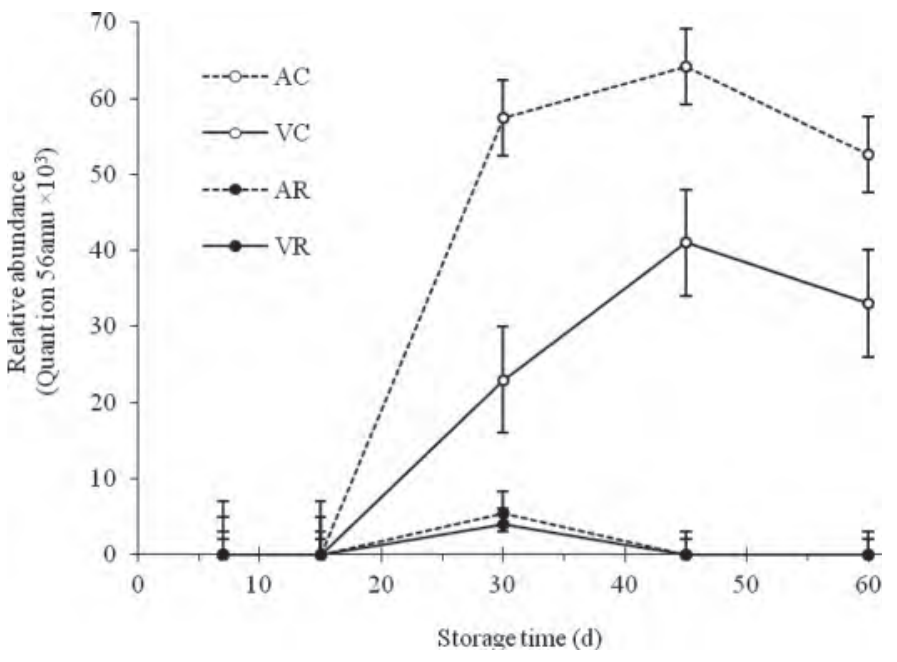

Figure 4. Effect of storage conditions on the evolution of hexanal during the shelf life of fresh goat milk cheese. Error bars indicate SD of duplicate analyses. $\mathrm{AC}=$ air packaging and storage in a display cabinet $\left(6^{\circ} \mathrm{C}\right)$ under fluorescent light; $\mathrm{VC}=$ partial-vacuum packaging and storage in a display cabinet $\left(6^{\circ} \mathrm{C}\right)$ under fluorescent light; $\mathrm{AR}=$ air packaging and storage in a dark room $\left(4^{\circ} \mathrm{C}\right) ; \mathrm{VR}=$ partial-vacuum packaging and storage in a dark room $\left(4^{\circ} \mathrm{C}\right)$.

increase in the peak areas of these peptides was observed (Figure 3), regardless of packaging type or light exposure. The peak area ratio $(100 \times \Sigma \mathrm{P}) / \alpha_{\mathrm{s} 1^{-}} \mathrm{CN}$ at $60 \mathrm{~d}$ more than doubled in comparison with the initial value at all storage conditions.

In this work, $\alpha_{s 1}$-I-CN peak area increased significantly during cheese storage across all storage conditions (Figure 3$)$. In any case, no difference $(P<0.05)$ between room and cabinet storage was observed. It is likely that $\alpha_{\mathrm{s} 1}-\mathrm{I}-\mathrm{CN}$ follows a dynamic evolution and its breakdown compensates formation in such a way that peak area ratio $\alpha_{\mathrm{s} 1}-\mathrm{I}-\mathrm{CN} / \alpha_{\mathrm{s} 1}-\mathrm{CN}$ is not as sensitive to temperature as soluble nitrogen. Conversely, the low degradation of $\beta$-CN observed in the CZE cheese patterns likely resulted from both reduced plasmin activity at the low $\mathrm{pH}$ of the cheese and the absence of curd cooking during cheesemaking. Overall, the CZE results suggested that (1) rennet played the primary role in the proteolysis of this cheese and (2) the formation and the progressive increase in peptides originating from $\alpha_{\mathrm{s} 1^{-}}$ $\mathrm{CN}$ proteolysis can be used to monitor the proteolytic phenomena occurring during aging.

\section{Analyses of VFA and Hexanal}

Cheese lipids may undergo hydrolytic or oxidative degradation during cheesemaking and ripening (McSweeney and Sousa, 2000). In this regard, the hydrolysis of triglycerides to FA and glycerol is considered to be essential for developing the flavor of goat milk 
Table 2. Mean sensory quality scores $( \pm \mathrm{SD})$ of goat milk cheeses ${ }^{1}$

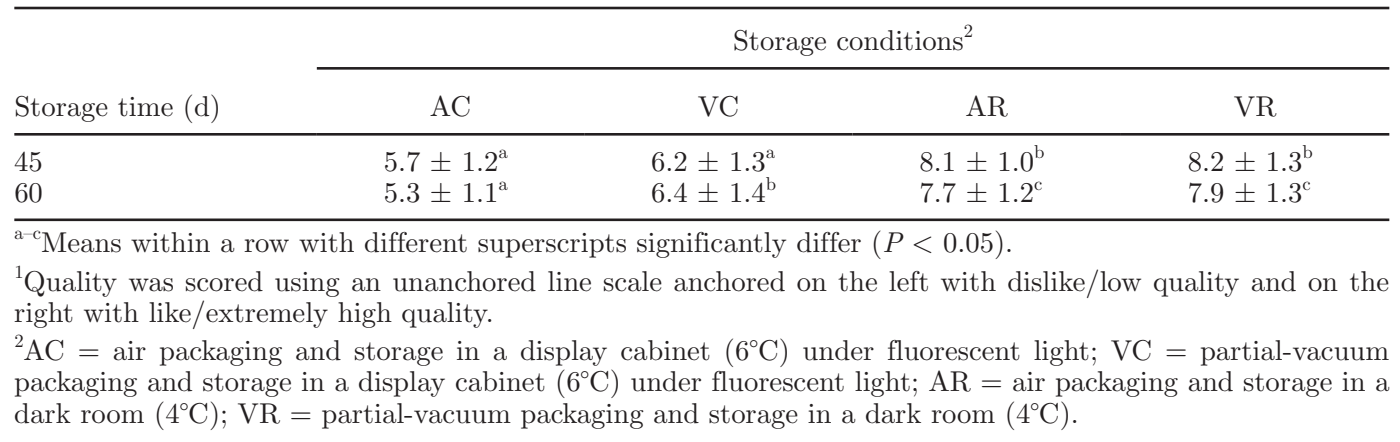

cheese because fat is characterized by a high level of short- and medium-chain FA.

Independent of cheese packaging conditions, a steady or slightly increasing trend for FA from $\mathrm{C} 4$ to $\mathrm{C} 10$ was recorded during storage, showing a limited triglycerides hydrolysis (results not shown). Two main factors could explain the weak lipolytic activity observed during storage. Jandal (1995) reported that milk pasteurization destroys most activities of the indigenous lipoprotein lipase in both cow and goat milk. In particular, this author verified that heating milk at $71^{\circ} \mathrm{C}$ for $15 \mathrm{~s}$ causes a reduction of lipoprotein lipase activity to 86 and $82 \%$ for cow and goat milk, respectively.

In this work, the in-batch thermization of the goat milk was expected to almost inactivate this enzyme. Second, Lactococcus spp. and Lactobacillus spp. are characterized by low lipolytic activity (Fox et al., 2000), whereas the contribution of Pseudomonas, the presence of which progressively decreased during the cheese shelf life, is expected to be negligible.

In the presence of oxygen and light, lipid oxidation can occur and several volatile organic compounds can be formed, giving rise to cheese off-flavors. Different authors (Park, 2001; Van Hekken et al., 2005) reported the rate of lipid oxidation to increase during storage, mirroring the temperature conditions. Light plays an important role in lipid oxidation when cheese is protected by packaging with transparent films that are ineffective against radiation. Hexanal is a molecule deriving from $\beta$-oxidation of linoleic and linolenic acids and it has been proposed as a marker of lipid oxidation. In this regard, the dark-stored samples showed very low levels of hexanal, regardless of the packaging. Conversely, levels of this compound increased sensitively in cheese samples stored in light under both packaging conditions (partial vacuum and air; Figure 4). No formation of hexanal occurred until d 15 of storage, at which point the accumulation increased rapidly in the presence of light. The maximum level of hexanal was recorded at $45 \mathrm{~d}$ in both the packaging conditions.

\section{Sensory Quality Evaluation}

Quality scores varied from 5.3 for AC to 8.2 for AR cheese (Table 2). The results of the sensory test showed that cheeses stored in the dark received the highest score in comparison with those kept under light $(P<$ $0.05)$, regardless of storage time (45 or $60 \mathrm{~d}$ ) and packaging conditions (air or partial vacuum). After 45-d storage, cheeses stored under partial vacuum or in the presence of air were not differently evaluated, irrespective of lighting conditions. At 60-d storage, VC cheeses were preferred $(P<0.05)$ to AC cheeses.

\section{CONCLUSIONS}

The presented data show that the chemical and microbiological properties of lactic goat milk cheese are affected slightly by storage length, temperature, and lighting conditions. As expected, cold dark storage reduces the oxidation of lipids in cheese. Overall, these data offer useful information for understanding the evolution of biochemical phenomena that occurs during retail storage of fresh goat milk cheese. The results on microbiological and chemical qualities and on sensory evaluation support that extending the shelf life of soft goat milk cheese from 45 to $60 \mathrm{~d}$ would be feasible.

\section{REFERENCES}

AOAC (Association of Official Analytical Chemists). 2000a. Official Method 989.10. Official Methods of Analysis. 17th ed. AOAC, Gaithersburg, MD.

AOAC (Association of Official Analytical Chemists). 2000b. Official Method 997.02. Official Methods of Analysis. 17th ed. AOAC, Gaithersburg, MD.

Barbosa, M. 2005. Interest in controlling alkaline phosphatase activity in sheep and goat milks. Bull. Int. Dairy Fed. 0501/Part 3:117127. IDF, Geneva, Switzerland.

Battelli, G., T. Silvetti, M. Decimo, and M. Brasca. 2011. Volatile organic compounds produced in milk by Enterococcus faecalis. Pages 75-76 in Proc. 10th Int. Mtg. Mountain Cheese, Dronero, Cuneo, Italy. Università degli Studi di Torino, Turin, Italy.

De Noni, I., and G. Battelli. 2008. Terpenes and fatty acid profiles of milk fat and "Bitto" cheese as affected by transhumance of cows on different mountain pastures. Food Chem. 109:299-309. 
Fox, P. F., T. P. Guinee, T. M. Cogan, and P. L. H. McSweeney. 2000. Fundamentals of Cheese Science. Aspen Publishers, Gaithersburg, MD

Gabiña, D. 2005. Panorama of sheep and goats dairy sectors. Bull. Int. Dairy Fed. 0501/Part 1:1-40. IDF, Geneva, Switzerland.

ICMSF (International Commission on Microbiological Specifications for Foods). 1978. Microorganisms in Foods. 1: Their Significance and Methods of Enumeration. 2nd ed. ICNSF, Toronto, Canada.

IDF (International Dairy Federation). 1997. Standard of identity for starter cultures of lactic acid bacteria. Standard 149A. IDF, Brussels, Belgium.

ISO/IDF (International Organization for Standardization/International Dairy Federation). 2001. International Standard ISO 8968 IDF 224. Milk. Determination of nitrogen content. Part 1: Kjeldahl method. ISO, Geneva, Switzerland and IDF, Brussels, Belgium.

ISO/IDF (International Organization for Standardization/International Dairy Federation). 2004. International Standard ISO 5534 IDF 4. Cheese and processed cheese. Determination of the total solids content (Reference method). ISO, Geneva, Switzerland and IDF, Brussels, Belgium.

ISO/IDF (International Organization for Standardization/International Dairy Federation). 2006. International Standard ISO/DIS 11816-1 IDF 155-1. Milk and milk products. Determination of alkaline phosphatase activity. Part 1: fluorometric method for milk and milk-based drinks. ISO, Geneva, Switzerland and IDF, Brussels, Belgium.

ISO/IDF (International Organization for Standardization/International Dairy Federation). 2010. Draft International Standard ISO/ DIS 27871 IDF 224. Cheese and processed cheese. Determination of the nitrogenous fractions. ISO, Geneva, Switzerland and IDF, Brussels, Belgium.

Jandal, J. M. 1995. Some factors affecting lipase activity in goat milk. Small Rumin. Res. 16:87-91.
Klotz, V., A. Hill, K. Warriner, M. Griffiths, and J. Odumeru. 2008. Assessment of the colorimetric and fluorometric assays for alkaline phosphatase activity in cow's, goat's and sheep's milk. J. Food Prot. $71: 1884-1888$

Masotti, F., J. A. Hogenboom, V. Rosi, I. De Noni, and L. Pellegrino. 2010. Proteolysis indices related to cheese ripening and typicalness in PDO Grana Padano cheese. Int. Dairy J. 20:352-359.

McSweeney, P. L. H., and M. J. Sousa. 2000. Biochemical pathways for the production of flavor compounds in cheeses during ripening: a review. Lait 80:293-324.

Molina, E., M. De Frutos, and M. Ramos. 2000. Capillary electrophoresis characterization of the casein fraction of cheeses made from cows', ewes' and goats' milks. J. Dairy Res. 67:209-216.

Park, Y. W. 2001. Proteolysis and lipolysis of goat milk cheese. J. Dairy Sci. 84(E. Suppl.):E84-E92.

Park, Y. W., J. H. Lee, and S. J. Lee. 2006. Effects of frozen and refrigerated storage on organic acid profiles of goat milk plain soft and Monterey jack cheeses. J. Dairy Sci. 89:862-871.

Recio, I., M. L. Perez-Rodriguez, L. Amigo, and M. Ramos. 1997. Study of the polymorphism of caprine milk caseins by capillary electrophoresis. J. Dairy Res. 64:515-523.

Singh, T. K., and K. R. Cadwallader. 2004. Ways of measuring shelflife and spoilage. Pages 165-183 in Understanding and Measuring the Shelf-life of Food. R. Steele, ed. Woodhead Publishing Ltd., Cambridge, UK.

Sousa, M. J., J. Ardö, and P. L. H. McSweeney. 2001. Advances in the study of proteolysis during cheese ripening. Int. Dairy J. $11: 327-345$.

Van Hekken, D. L., M. H. Tunick, and Y. W. Park. 2005. Effect of frozen storage on the proteolytic and rheological properties of soft caprine milk cheese. J. Dairy Sci. 88:1966-1972. 